\title{
Musculo-skeletal Ultrasound in paediatric rheumatology: experience of one University Hospital
}

\author{
J Madruga Dias", M Manuela Costa, F Saraiva, JA Pereira da Silva \\ From 18th Pediatric Rheumatology European Society (PReS) Congress \\ Bruges, Belgium. 14-18 September 2011
}

\section{Introduction}

Musculo-skeletal Ultrasound (MSK-US) has become essential in the diagnosis and follow-up of children with rheumatic diseases. It's an innocuous exam that helps diagnostic and treatment decisions and allows treatment efficacy assessment.

\section{Objectives}

To evaluate the usefulness of MSK-US in the study of paediatric rheumatic inflammatory diseases.

\section{Material and methods}

Analysis of 330 MSK-US exams performed to 222 children with rheumatic inflammatory diseases in our Department. The children's ages were between 1 and 18 years (average $=11,7 \pm 4,7$ years) and $67,6 \%$ were female. Synovial membrane proliferation, intra-articular effusion, cartilage contour abnormalities, erosions and periarticular affections were searched in each joint. Clinical and ultrasonographic data were correlated.

\section{Results}

MSK-US detected synovitis in 100 of 194 exams $(51,5 \%)$ of patients that had clinical suspicion of arthritis and in 36 of 136 exams $(26,5 \%)$ of patients that presented with another symptom. In patients with clinical, but not ultrasonographic synovitis (94), we detected tenosynovitis in 13 cases $(13,8 \%)$ and synovial cyst in $4(4,3 \%)$. The remaining patients had no ultrasonographic changes.

Overall 39 exams showed ultrasonographic tenosynovitis, $15(38,5 \%)$ of which had the clinical diagnosis too.

* Correspondence: joao_alexandre@hotmail.com

Department of Rheumatology, Hospital de Santa Maria, Lisbon, Portugal
MSK-US also identified erosions in 7 patients (2 had no ultrasonographic arthritis).

In total, 381 ultrasonographic diagnoses were made. Considering that $49,7 \%$ of the exams performed had no abnormalities, 1,3 diagnosis per exam were made.

\section{Conclusions}

MSK US confirms or excludes arthritis, which permits a fast treatment or correct therapeutic options, avoiding iatrogenesis in children. It also allows the diagnosis of other articular and periarticular affections, and ultrasound-guided procedures.

Published: 14 September 2011

doi:10.1186/1546-0096-9-S1-P42

Cite this article as: Dias et al:: Musculo-skeletal Ultrasound in paediatric rheumatology: experience of one University Hospital. Pediatric

Rheumatology 2011 9(Suppl 1):P42. and take full advantage of:

- Convenient online submission

- Thorough peer review

- No space constraints or color figure charges

- Immediate publication on acceptance

- Inclusion in PubMed, CAS, Scopus and Google Scholar

- Research which is freely available for redistribution 